\title{
Iron, Iodine and Selenium Effects on Quality, Shelf Life and Microbial Activity of Cherry Tomatoes
}

\author{
Mohammad Z. ISLAM ${ }^{1,2}$, Mahmuda A. MELE ${ }^{1}$, Jun P. BAEK ${ }^{3}$, \\ Ho-Min $\mathrm{KANG}^{1,2 *}$ \\ ${ }^{1}$ Kangwon National University, Division of Horticulture and Systems Engineering, Program of Horticulture, Chuncheon 24341, \\ Korea; mele@kangwon.ac.kr; hominkang@kangwon.ac.kr (*correspondingauthor) \\ ${ }^{2}$ Kangwon National University, Agriculture and Life Science Research Institute, Chuncheon 24341, Korea; zabir@kangwon.ac.kr \\ ${ }^{3}$ Catholic Sangji College, Department of Converged and Integrated Agro-Industry Science, Andong 36686, Korea; jpwhite74@gmail.com
}

\begin{abstract}
Tomatoes have high nutritional and economical value and its deterioration start after harvest. They need proper treatments to increase and maintain quality as well as shelf life. The objective of this study was to determine the effect of iron, iodine and selenium on quality, shelf life and microbial activity of cherry tomatoes. Iron $(1 \mathrm{mg} / \mathrm{L})$, iodine $(1 \mathrm{mg} / \mathrm{L})$ and selenium $(1 \mathrm{mg} / \mathrm{L})$ were supplied with nutrient solution for five weeks prior to harvest. Then, cherry tomatoes were stored at $5^{\circ} \mathrm{C}$ to assess quality, shelf life and microbial activity. The highest Ca content $(p<0.05)$ revealed in selenium-treated cherry tomatoes. Lower respiration and ethylene production were showed in selenium-treated cherry tomatoes both harvest time and after storage compared with iron and iodine treatments. At harvest time and after storage, the respiration were $1.29(p<0.05)$ and $0.62 \mathrm{~mL} / \mathrm{kg} / \mathrm{hr}(p<0.01)$, respectively in selenium-treated cherry tomatoes. Moreover at harvest time and after storage in selenium-treated cherry tomatoes, the ethylene production was 2.11 and $0.87 \mu \mathrm{L} / \mathrm{kg} / \mathrm{hr}(p<0.01)$, respectively. The lowest fresh weight loss, the longest shelf life $(p<0.01)$, the least fungal incidence rate and microbial activities were found in selenium-treated cherry tomatoes. The longest shelf life of selenium-treated cherry tomatoes was 22 days. Selenium-treated cherry tomatoes' firmness increased $(16.82 \mathrm{~N})$ at harvest time $(p<0.05)$ and it was significantly retained $(12.70 \mathrm{~N})$ after storage $(p<0.01)$. Color development and lycopene content were more suppressed by selenium treatment after storage than iron and iodine treatments. Titratable acidity, vitamin $\mathrm{C}$ and soluble solids increased in selenium-treated cherry tomatoes after storage. Based on results, selenium-treated cherry tomatoes have significant potential to increase and maintain quality and shelf life.
\end{abstract}

Keywords: bacteria; firmness; fungi; respiration rate; Solanum lycopersicum

\section{Introduction}

Tomato (Solanum lycopersicum) is widely cultivated fruits and according to FAO (FAOSTAT, 2014), tomatoes harvested area was 7070 hectares, the production was 499960 tonnes, and yield was 707157 hectogram/hectare (calculated data) in Korea. Tomato has economical and nutritional values, and its pulp and seed obtain oil (Giuffrè and Capocasale, 2015; Giuffrè and Capocasale, 2016).

Iron, iodine and selenium are trace elements and plants need low concentrations (Broadley et al., 2012) that may have beneficial effects on quality, shelf life and microbial decontamination of cherry tomatoes. These elements are needed for plants as well as animals and humans. As plant can uptake these elements, so human can get from edible parts of plants. Close to $80 \%$ iron is localized in the chloroplast of growing leaves, stored in the stomata of plastids, and a deficient plant revealed a lower photosynthesis (Broadley et al., 2012).

Iodine can have a positive effect on the physiological, biochemical and molecular nature of plants (KabataPendias, 2011) but plants' reaction to physiological and biochemical from iodine is unclear (Smolen et al., 2014). The basic role of iodine in the biosynthesis of thyroid hormones - thyroxin and triiodothyronine is monitoring plants' physiological and biochemical processes (Smolen et al., 2015). Globally, two-third of the population suffers from diseases because of insufficient iodine and selenium intake (Kabata-Pendias, 2011). Iodine and selenium may be easily transported through plants xylem (White and 
Broadley, 2009) and $\mathrm{SeO}_{4}^{2-}$ form may be redistributed through plants' phloem (White et al., 2007).

Selenium is associated with the oxygen-sulfur-tellurium group and plants usually enable transfer from soil to the food chain although it has not been validated as an essential plant nutrient (Edelstein et al., 2016). It regulates antioxidants and reactive oxygen species (ROS), inhibits uptake of heavy metal, rebuilds cell membrane and chloroplast structures, maintains the photosynthetic system, regulates minerals uptake and distributes in the antioxidative systems, makes ion balance, and increases cell integrity (Feng et al., 2013). Selenium treatment increases selenium content in peaches, pears and cherry tomatoes (Pezzarossa et al., 2012; Pezzarossa et al., 2014).

There is insufficient research on iron, iodine and selenium in the hydroponic system of nutrient film technique (NFT) relative to use in large-scale production of cherry tomatoes. This study was conducted to determine the effect of iron, iodine and selenium on quality, shelf life and microbial activity of cherry tomatoes in the hydroponic system of NFT.

\section{Materials and Methods}

\section{Fruitmaterial and treatments}

Cherry tomatoes (Solanum lycopersicum cv. 'Unicorn') were grown hydroponically at summer in 2016 with EC 2.3 $\mathrm{dS} \mathrm{m}^{-1}$ and $\mathrm{pH}$ 5.8-6.2 supplied nutrient solution based on the Japanese horticultural experiment station in the Republic of Korea. The plastic house was equipped with electrical fan to maintain maximum $32{ }^{\circ} \mathrm{C}$ temperature. The following treatments were used: (1) control (nontreatment); (2) $1 \mathrm{mg} \mathrm{L}^{-1}$ iron (Fe) from Fe-EDTA $\left(\mathrm{C}_{10} \mathrm{H}_{13} \mathrm{FeN}_{2} \mathrm{O}_{8}\right.$ ) (Smolen et al., 2014); (3) $1 \mathrm{mg} \mathrm{L}^{-1}$ iodine (I) from potassium iodide (KI) (Li et al., 2017); and (4) 1 mg L ${ }^{-1}$ selenium $(\mathrm{Se})$ from sodium selenate $\left(\mathrm{Na}_{2} \mathrm{SeO}_{3}\right)$ (Pezzarossa et al., 2014). They were applied for five weeks prior to harvest in nutrient solution of 10 plants in each treatment. The $31.17 \mathrm{~mm}$ sizes cherry tomatoes harvest time quality was measured at room temperature $\left(20^{\circ} \mathrm{C}\right)$. Harvested rest of tomatoes were kept at $5{ }^{\circ} \mathrm{C}$ with $85 \%$ relative humidity (Islam et al., 2013) to measure fruit quality, shelf life and microbial activity.

\section{Mineral contents}

Minerals were measured according to Simsek and Aykut (2007) and Islam et al. (2016). Inductively coupled plasmaatomic emission spectroscopy (Integra XL Dual, GBC, and Melbourne, Victoria) were used to measure minerals content.

\section{Fruit physiology parameters}

A PBI Dansensor (CheckMate 9900, Denmark) was used to measure carbon dioxide and oxygen. Ethylene was measured with a GC-2010 Shimadzu chromatograph (Shimadzu Corporation, Japan) (Mele et al., 2017).

\section{Fruits quality parameters}

Fresh weight loss of cherry tomatoes was measured on the basis of Mele et al. (2017) by subtracting present to previous weight loss and converting to percentage. Visual quality was observed on the scale of 1 to $5(1=$ very bad, $2=$ bad, $3=$ good, marketable, $4=$ very good, and $5=$ excellent) during $5{ }^{\circ} \mathrm{C}$ storage for 25 days and five panel members were designated to assess visual quality and fungus of the cherry tomatoes (Islam et al., 2016). Shelf life was measured according to visual quality ( $\geq 3$; good, marketable) and determinants such as mold growth, decay, shriveling, smoothness, shininess, and homogeneity. Number of fungus-contaminated cherry tomatoes was counted and they were converted to fungal incidence percentage.

A fruit hardness tester (Lutron FR 5105, Taiwan) was used to measure firmness. Skin color values of the cherry tomatoes were measured using a chroma meter model CR400 (Konica Minolta Sensing, Inc., Japan). Lycopene content was measured according to Fish et al. (2002).

A refractometer (Atago U.S.A. Inc., U.S.A.) was used to measure soluble solid. Titratable acidity was measured by a fruit acid meter (G-Won Hi-tech, Korea). Vitamin C was analyzed according to Islam et al. (2016) with Waters HPLC (Waters Associates, Milford, MA, USA) and the column was $\mathrm{C}_{18}(250 \mathrm{~mm} \times 46 \mathrm{~mm}, 5 \mu \mathrm{m}$, Agilent, USA) at $265 \mathrm{~nm}$.

\section{Count of bacteria and fungi}

A chilled $\left(4^{\circ} \mathrm{C}\right)$ cherry tomato slice $\left(3 \mathrm{~cm}^{2}\right)$ was poured in $10 \mathrm{ml}$ of $0.1 \%$ peptone for sterile and shaken. Nutrient agar (NA) and potato dextrose agar (PDA) were used for bacteria and fungi accordingly.

Plates were incubated for two days at $37^{\circ} \mathrm{C}$ for bacteria and five days at $25^{\circ} \mathrm{C}$ for fungi. After finishing incubation, bacteria and fungi were identified based on colony characterization and microscopic methods.

\section{Statistical analysis}

Significant differences of mean values were determined using Duncan's multiple range test (DMRT) of the one-way ANOVA by SPSS V. 16 (SPSS Inc., Chicago, USA).

\section{Results and Discussion}

\section{Mineral contents}

Higher $\mathrm{CaO}, \mathrm{K}_{2} \mathrm{O}, \mathrm{MgO}$, and $\mathrm{P}_{2} \mathrm{O}_{5}$ content was found in selenium-treated cherry tomatoes compared with other treatments (Table 1). Selenium increased cytosolic $\mathrm{Ca}$ in Arabidopsis plants (Pilon-Smits and Quinn, 2010), and it increased $\mathrm{Ca}, \mathrm{K}, \mathrm{Mg}, \mathrm{Na}$, and $\mathrm{P}$ in Lycopersicon root and hypocotyl (Colak et al., 2014). Ca increase firmness, cell-wall thickness and shelf life of cherry tomato fruits (Islam $e t$ al., 2016). Therefore, selenium-treated cherry tomatoes increase quality and shelf life.

\section{Fruits physiology parameters}

The lowest respiration rate and ethylene production were found for selenium-treated cherry tomatoes, followed by iodine, iron and control tomatoes at harvest time and after storage (Fig. 1). Selenium maintained cherry tomatoes, lettuce and chicory quality by suppressing respiration rate and ethylene production at harvest time and during storage (Malorgio et al., 2009; Pezzarossa et al., 2014; Zhu et al., 2017). The lowest respiration rate and ethylene production are desirable to maintain quality and increase shelf life of cherry tomatoes. 
390

Table 1. Mineral content of cherry tomato fruits which treated by iron, iodine and selenium

\begin{tabular}{|c|c|c|c|c|c|c|c|c|c|}
\hline \multirow{2}{*}{ Parameter } & \multicolumn{5}{|c|}{$\%$} & \multicolumn{4}{|c|}{$\mathrm{mg} \mathrm{kg}^{-1}$} \\
\hline & $\mathrm{CaO}$ & $\mathrm{K}_{2} \mathrm{O}$ & $\mathrm{MgO}$ & $\mathrm{NaO}$ & $\mathrm{P}_{2} \mathrm{O}_{5}$ & $\mathrm{Fe}$ & $\mathrm{Mn}$ & $\mathrm{Cu}$ & $\mathrm{Zn}$ \\
\hline Control & $0.107 b^{2}$ & $2.103 \mathrm{~b}$ & $0.130 \mathrm{~b}$ & $0.133 \mathrm{~b}$ & $0.447 \mathrm{~b}$ & $0.127 \mathrm{~b}$ & $0.040 \mathrm{a}$ & $0.037 \mathrm{a}$ & $0.097 \mathrm{a}$ \\
\hline Iron & $0.123 \mathrm{ab}$ & $2.367 \mathrm{ab}$ & $0.140 \mathrm{ab}$ & $0.150 \mathrm{ab}$ & $0.513 \mathrm{ab}$ & $0.163 a$ & $0.043 a$ & $0.067 \mathrm{a}$ & $0.093 \mathrm{a}$ \\
\hline Iodine & $0.113 \mathrm{ab}$ & $2.303 \mathrm{ab}$ & $0.150 \mathrm{ab}$ & $0.137 \mathrm{~b}$ & $0.540 \mathrm{ab}$ & $0.150 \mathrm{ab}$ & $0.047 \mathrm{a}$ & $0.030 \mathrm{a}$ & $0.100 \mathrm{a}$ \\
\hline Selenium & $0.130 \mathrm{a}$ & $2.540 \mathrm{a}$ & $0.153 a$ & $0.163 a$ & $0.653 \mathrm{a}$ & $0.157 \mathrm{ab}$ & $0.050 \mathrm{a}$ & $0.033 \mathrm{a}$ & $0.103 \mathrm{a}$ \\
\hline$p$-value & * & * & * & ** & ** & $* *$ & NS & NS & NS \\
\hline
\end{tabular}

Note: ${ }^{2}$ Mean separation of columns by Duncan's multiple range tests (DMRT) $(\mathrm{n}=10) . \mathrm{NS},{ }^{*},{ }^{* *} ;$, not significant, or significant at $\mathrm{p}<0.05$, and 0.01 , respectively
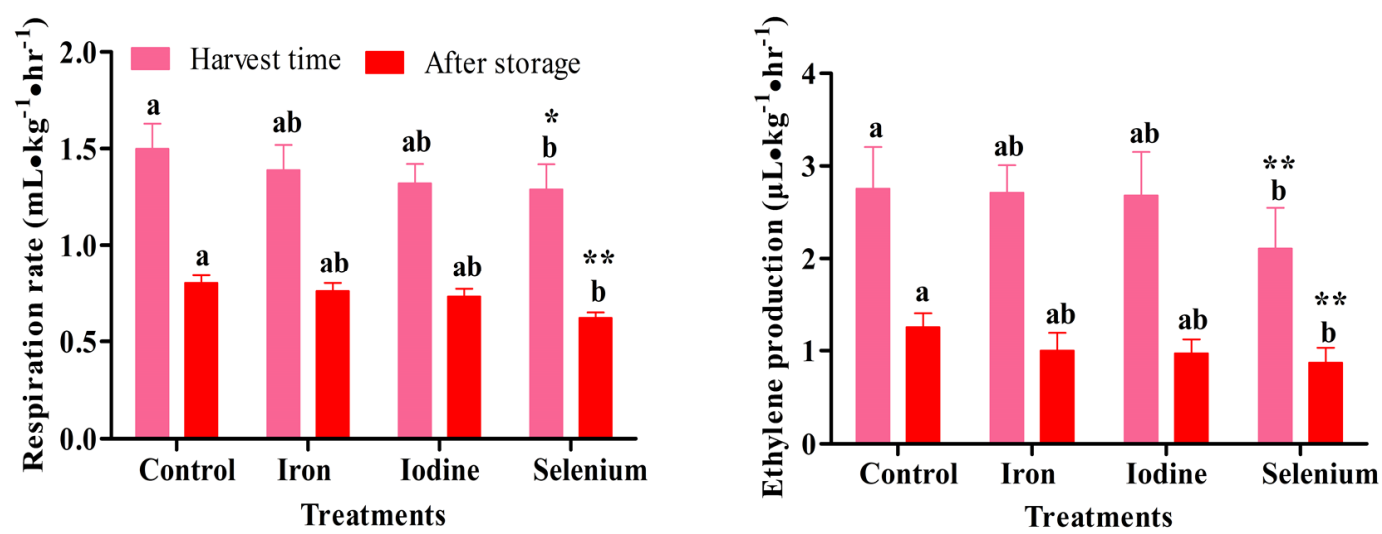

Fig. 1. Respiration and ethylene production rate of cherry tomatoes at harvest time $\left(0\right.$ day at $\left.20^{\circ} \mathrm{C}\right)$ and after storage $\left(25^{\text {th }}\right.$ day at $\left.5^{\circ} \mathrm{C}\right) .{ }^{*},{ }^{* *}$; significant at $\mathrm{p}<0.05$ and 0.01 of Duncan's multiple range tests (DMRT). Each data point is the mean of five double fruit replicates \pm standard error

\section{Fruits quality parameters}

Selenium-treated cherry tomatoes revealed the lowest fresh weight loss compared with control and it is related to Zhu et al. (2017). Fresh weight loss may be influenced by respiration, transpiration, and moisture loss of cherry tomatoes (Islam et al., 2016). The highest visual quality and longest shelf life were attributed to selenium-treated cherry tomatoes in maintaining marketable visual quality $(\geq 3)$. Lettuce and chicory of selenium treatment improved shelf life by decreasing ethylene production (Malorgio et al., 2009). Fungal incidence of selenium-treated cherry tomatoes was the lowest (Table 2) that can extend shelf life by maintaining quality. Selenium decreased fungal incidence in harvested cherry tomatoes by affecting intracellular ROS and plasma membrane of pathogens (Wu et al., 2016).

Highest firmness was revealed in selenium-treated cherry tomatoes at harvest time and after storage (Table 3). Firmness was higher in selenium-treated peaches, pears and cherry tomatoes compared with control at harvest time and after storage (Pezzarossa et al., 2012; Zhu et al., 2016) and occurred because of less ethylene production (Malorgio et al., 2009) that prevented softening of cherry tomatoes.
Color, lycopene, titratable acidity, vitamin $\mathrm{C}$ and soluble solids did not reveal significant differences at harvest with treatments, as selected cherry tomatoes were similar maturity-stage fruits (light red). Parameters revealed significant differences after storage in red maturity-stage cherry tomatoes. Color development and lycopene content of selenium-treated cherry tomatoes were lowest after storage (Table 3). Selenium effectively delays ripening because of less ethylene biosynthesis, controlling ROS level and oxidative damage (Pezzarossa et al., 2012; Zhu et al., 2017).

Highest titratable acidity and vitamin $\mathrm{C}$ content were observed in selenium-treated cherry tomatoes after storage (Table 4), and this result is related with Zhu et al. (2016). Soluble solids content was higher in selenium-treated cherry tomatoes compared with control after storage and may occur because of the breakdown of disaccharide (sucrose) into monosaccharide (fructose and glucose). Soluble solids content was highest in selenium-treated peaches, pears and cherry tomatoes after storage (Pezzarossa et al., 2012; Zhu et al., 2016).

Table 2. Fruit fresh weight loss, visual quality, shelf life and fungal incidence of cherry tomato after storage $\left(25^{\text {th }}\right.$ day at $\left.5^{\circ} \mathrm{C}\right)$

\begin{tabular}{|c|c|c|c|c|}
\hline Parameter & Fresh weight loss (\%) & Visual quality & Shelf life (days) & Fungal incidence (\%) \\
\hline Control & $3.90 b^{z}$ & $2.20 \mathrm{~b}$ & $17 \mathrm{~b}$ & $26.50 \mathrm{a}$ \\
\hline Iron & $3.55 \mathrm{ab}$ & $2.50 \mathrm{ab}$ & $20 \mathrm{ab}$ & $24.00 \mathrm{ab}$ \\
\hline Iodine & $3.20 \mathrm{ab}$ & $2.35 \mathrm{ab}$ & $18 \mathrm{ab}$ & $21.50 \mathrm{ab}$ \\
\hline Selenium & $2.81 \mathrm{~b}$ & $2.70 \mathrm{a}$ & $22 \mathrm{a}$ & $18.00 \mathrm{~b}$ \\
\hline P value & $* *$ & ** & $* *$ & * \\
\hline
\end{tabular}

Note: ${ }^{2}$ Mean separation of columns by Duncan's multiple range tests (DMRT) $(\mathrm{n}=10) .{ }^{*},{ }^{* *}$; significant at $\mathrm{p}<0.05$ and 0.01 , respectively. 
Table 3. Fruit firmness, color, and lycopene of cherry tomato at harvest time $\left(0\right.$ day at $\left.20^{\circ} \mathrm{C}\right)$ and after storage $\left(25^{\text {th }}\right.$ day at $\left.5^{\circ} \mathrm{C}\right)$

\begin{tabular}{|c|c|c|c|c|c|c|}
\hline \multirow{2}{*}{ Parameter } & \multicolumn{2}{|c|}{ Firmness (N) } & \multicolumn{2}{|c|}{$\operatorname{Color}\left(a^{*} / b^{*}\right)$} & \multicolumn{2}{|c|}{ Lycopene $\left(\mathrm{mg} \mathrm{kg}^{-1} \mathrm{FW}\right)$} \\
\hline & Harvest & Storage & Harvest & Storage & Harvest & Storage \\
\hline Control & $14.10 b^{z}$ & $10.27 \mathrm{~b}$ & $0.65 a$ & $0.97 \mathrm{a}$ & $90.62 \mathrm{a}$ & $106.09 \mathrm{a}$ \\
\hline Iron & $15.09 \mathrm{ab}$ & $10.88 \mathrm{ab}$ & $0.66 \mathrm{a}$ & $0.93 \mathrm{ab}$ & $90.09 \mathrm{a}$ & $102.70 \mathrm{ab}$ \\
\hline Iodine & $15.86 \mathrm{ab}$ & $11.03 \mathrm{ab}$ & $0.65 a$ & $0.92 \mathrm{ab}$ & $90.27 \mathrm{a}$ & $102.39 \mathrm{ab}$ \\
\hline Selenium & $16.82 \mathrm{a}$ & $12.70 \mathrm{a}$ & $0.66 \mathrm{a}$ & $0.91 b$ & $90.52 \mathrm{a}$ & $98.87 \mathrm{~b}$ \\
\hline Pvalue & * & ** & NS & * & NS & * \\
\hline
\end{tabular}

Note: ${ }^{2}$ Mean separation of columns by Duncan's multiple range tests (DMRT) ( $\left.\mathrm{n}=10\right) . \mathrm{NS},{ }^{*},{ }^{* *}$; not significant, or significant at $\mathrm{p}<0.05$ and 0.01 , respectively.

Table 4. Fruit titratable acidity, vitamin $\mathrm{C}$ and soluble solids of cherry tomato at harvest time $\left(0\right.$ day at $\left.20^{\circ} \mathrm{C}\right)$ and after storage $\left(25\right.$ th day at $\left.5{ }^{\circ} \mathrm{C}\right)$

\begin{tabular}{|c|c|c|c|c|c|c|}
\hline \multirow{2}{*}{ Parameter } & \multicolumn{2}{|c|}{ Titratable acidity (\% citric acid) } & \multicolumn{2}{|c|}{ Vitamin C (mg $\left.100 \mathrm{~g}^{-1} \mathrm{FW}\right)$} & \multicolumn{2}{|c|}{ Soluble solids ( ${ }^{\circ}$ Brix $)$} \\
\hline & Harvest & Storage & Harvest & Storage & Harvest & Storage \\
\hline Control & $1.04 \mathrm{a}^{2}$ & $0.80 \mathrm{~b}$ & $17.56 \mathrm{a}$ & $10.09 \mathrm{~b}$ & $6.68 \mathrm{a}$ & $8.27 b$ \\
\hline Iron & $1.04 \mathrm{a}$ & $0.81 \mathrm{ab}$ & $17.70 \mathrm{a}$ & $11.86 \mathrm{ab}$ & $6.69 \mathrm{a}$ & $8.42 \mathrm{ab}$ \\
\hline Iodine & $1.03 a$ & $0.84 \mathrm{ab}$ & $17.52 \mathrm{a}$ & $12.47 \mathrm{ab}$ & $6.67 \mathrm{a}$ & $8.35 \mathrm{ab}$ \\
\hline Selenium & $1.04 \mathrm{a}$ & $0.89 \mathrm{a}$ & $17.94 \mathrm{a}$ & $14.37 \mathrm{a}$ & $6.69 \mathrm{a}$ & $8.57 \mathrm{a}$ \\
\hline Pvalue & NS & $*$ & NS & *** & NS & $*$ \\
\hline
\end{tabular}

Table 5. Count of the microbial activity associated with tomato fruits at different treatments of cherry tomato at harvest time $\left(0\right.$ day at $\left.20^{\circ} \mathrm{C}\right)$ and after storage $\left(25\right.$ th day at $\left.5^{\circ} \mathrm{C}\right)$

\begin{tabular}{ccccc}
\hline \multirow{2}{*}{ Parameter } & \multicolumn{2}{c}{ Bacteria $(\times 10$ spores $/ \mathrm{ml})$} & Fungi $(\times 10$ spores $/ \mathrm{ml})$ \\
\cline { 2 - 5 } & Harvest & Storage & $6.00 \mathrm{a}$ & Storage \\
\hline Control & $200.00 \mathrm{a}^{2}$ & $206.67 \mathrm{a}$ & $4.67 \mathrm{ab}$ & $6.00 \mathrm{a}$ \\
Iron & $196.67 \mathrm{ab}$ & $201.67 \mathrm{ab}$ & $4.33 \mathrm{ab}$ & $6.33 \mathrm{ab}$ \\
Iodine & $195.00 \mathrm{ab}$ & $199.33 \mathrm{ab}$ & $3.33 \mathrm{~b}$ & $4.67 \mathrm{ab}$ \\
Selenium & $188.33 \mathrm{~b}$ & $193.33 \mathrm{~b}$ & $*$ \\
P value & ${ }^{*}$ & $*$ & ${ }^{*}$ & $*$ \\
\hline Note: ${ }^{2}$ Mean separation of columns by Duncan's multiple range tests $(\mathrm{DMRT})(\mathrm{n}=10) .{ }^{*} ;$ significant at $\mathrm{p}<0.05$. & &
\end{tabular}

\section{Count of bacteria and fungi}

All treatments revealed distinctive effectiveness in diminishing bacteria and fungi occurrence either at harvest time or after storage compared with control. Lowest bacterial and fungal count was revealed in selenium-treated cherry tomatoes at harvest time and after storage. Bacteria at harvest time or after storage were higher than fungal densities (Table 5). Selenium effectively reduced gray mold of cherry tomatoes caused by Botrytis cinerea and control from severe damage to the conidia plasma membrane and loss of cytoplasmic materials from the hyphae (Wu et al., 2016).

\section{Conclusions}

Effects of iron, iodine and selenium on quality, shelf life and microbial activity of cherry tomatoes were examined in this study. Selenium-treated cherry tomatoes revealed the lowest respiration rate and ethylene production that slowed the ripening process. The least fresh weight loss and the longest shelf life was revealed in selenium-treated cherry tomatoes among treatments. Tomatoes firmness was increased at harvest time and it retained after storage with selenium treatment. Fungal incidence and microbial activities were also lower in selenium-treated cherry tomatoes compared with iron and iodine treatments. Therefore, selenium treatment may be a useful tool to maintain quality and shelf life for cherry tomatoes by reducing microbial activities.

\section{Acknowledgements}

This research work was sponsored by the Korea Institute Planning and Evaluation Technology (IPET) in Food, Agriculture, Forestry and Fisheries of Export Promotion Technology Development Program, and fund provided Agriculture Ministry, Food, and Rural Affairs (MAFRA) (314027-3).

\section{References}

Broadley M, Brown P, Cakmak I, Rengel Z, Zhao F (2012). Function of nutrients: micronutrients. In: Marschner P (Ed). Mineral Nutrition of Higher Plants. Third edition, Academic Press, Elsevier.

Colak G, Baykul MC, Gurler R, Catak E, Caner N (2014). The effects of selenium on Lycopersicon esculentum Mill. Seedlings. Pakistan Journal of Botany 46:911-920.

Edelstein M, Berstein D, Shenker M, Azaizah H, Ben-Hur M (2016). Effects of selenium on growth parameters of tomato and basil under fertigation management. HortScience 51:1050-1056.

FAOSTAT (2014). Food and Agriculture Organization (FAO) of the United Nations, http://faostatfaooorg.

Feng R, Wei C, Tu S (2013). The roles of selenium in protecting plants against abiotic stresses. Environmental and Experimental Botany 87:5868. 
392

Fish WW, Perkins-Veazie P, Collins JK (2002). A quantitative assay for lycopene that utilizes reduced volumes of organic solvents. Journal of Food Composition and Analysis 15:309-317.

Giuffrè AM, Capocasale M (2015). Policosanol in tomato seed oil (Solanum lycopersicum L.): the effect of cultivar. Journal of Oleo Science 64:625631.

Giuffrè AM, Capocasale M (2016). Sterol composition of tomato (Solanum bycopersicum L.) seed oil: theeffect of cultivar. International Food Research Journal 23:116-122.

Islam MZ, Baek JP, Kim YS, Kang HM (2013). Characteristics of chilling symptoms of cherry tomato compared to beefsteak tomato harvested at different ripening stages. Journal of Pure and Applied Microbiology 7:703-709.

Islam MZ, Mele MA, Baek JP, Kang HM (2016). Cherry tomato qualities affected by foliar spraying with boron and calcium. Horticulture, Environment and Biotechnology 57:46-52.

Kabata-Pendias A (2011). TraceElements in Soil and Plants, Fourth edition. CRCPress, Taylor and Francis Group.

Li R, Li DW, Liu HP, Hong CL, Song MY, DaiZX, ... Weng HX (2017). Enhancing iodine content and fruit quality of pepper (Capsicum annuum L.) through biofortification. Scientia Horticulturae 214:165173.

Malorgio F, Diaz K, Ferrante A, Mensuali A, Pezzarossa B (2009). Effects of selenium addition on minimally processed leafy vegetables grown in floating system. Journal of the Science of Food and Agriculture 89:22432251.

Mele MA, Islam MZ, Baek JP, Kang HM (2017). Quality, storability, and essential oil content of Ligularia fischeri during modified atmosphere packaging storage. Journal of Food Science and Technology 54:743750.

Pezzarossa B, Remorini D, Gentile M L, Massai R (2012). Effects of foliar and fruit addition of sodium selenate on selenium accumulation and fruit quality.Journal of the Science of Food and Agriculture 92:781-786.

Pezzarossa B, Rosellini I, Borghesi E, Tonutti P, Malorgio F (2014). Effects of Se-enrichment on yield, fruit composition and ripening of tomato (Solanum lycopersicum) plants grown in hydroponics. Scientia Horticulturae 165:106-110.
Pilon-Smits EAH, Quinn CF (2010). Selenium metabolism in plants. In: Hell R, Mendel RR (Eds). Cell Biology of Metals and Nutrients, Plant Cell Monographs 17,Springer-VerlagBerlin Heidelberg.

Simsek A, Aykut O (2007). Evaluation of the microelement profile of Turkish hazelnut (Corylus avellana $\mathrm{L}$.) varieties for human nutrition and health. International Journal of Food Sciences and Nutrition 58:677688.

Smolen S, Kowalska I, Sady W (2014). Assessment of biofortification with iodine and selenium of lettuce cultivated in the NFT hydroponic system. Scientia Horticulturae 166:9-16.

Smolen S, Wierzbinska J, Sady W, Kotton A, Wiszniewska A, LiszkaSkoczylas M (2015). Iodine biofortification with additional application of salicylic acid affects yield and selected parameters of chemical composition of tomato fruits (Solanum lycopersicum L.). Scientia Horticulturae 188:89-96.

White PJ, Broadley MR, Bowen HC, Johnson SE (2007). Selenium and its relationship with sulfur. In: Hawkesford MJ, de Kok LJ (Eds). Sulfur in Plants-AnEcological Perspective. Springer,London, UK.

White PJ, Broadley MR (2009). Biofortification of crops with seven mineral elements often lacking in human diets - iron, zinc, copper, calcium, magnesium, selenium and iodine. New Phytologist 82:49-84.

WuZ, Yin X, Bañuelos GS, Lin ZQ,ZhuZ, Liu Y,... Li M (2016).Effect of selenium on control of postharvest gray mold of tomato fruit and the possible mechanismsinvolved. Frontiers Microbiology 6:1-11.

Zhu Z, Chen Y,Zhang X, Li M (2016). Effect of foliar treatment of sodium selenate on postharvest decay and quality of tomato fruits. Scientia Horticulturae 198:304-310.

Zhu Z, Chen Y, Shi G, Zhang X (2017). Selenium delays tomato fruit ripening by inhibiting ethylene biosynthesis and enhancing the antioxidant defense system. Food Chemistry 219:179-184. 